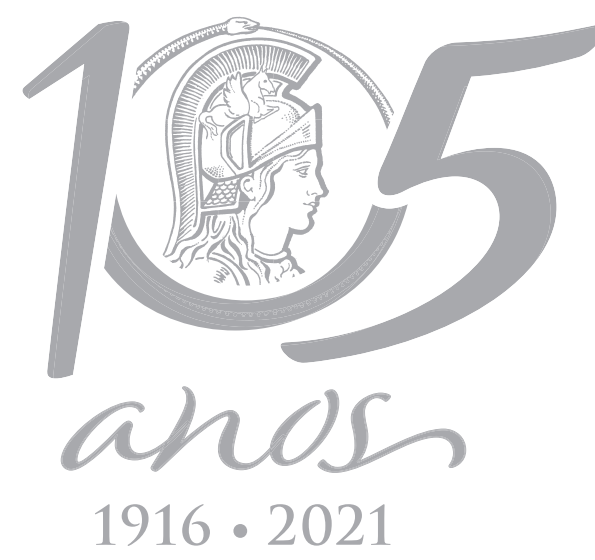

\title{
ECOSYSTEMS
}

\section{When the tail shakes the snake: phylogenetic affinities and morphology of Atractus badius (Serpentes: Dipsadidae), reveals some current pitfalls on the snake's genomic age}

\author{
PAULO PASSOS, PAULO R. MELO-SAMPAIO, LUCIANA O. RAMOS, FELIPE G. \\ GRAZZIOTIN, ANTOINE FOUQUET \& OMAR TORRES-CARVAJAL
}

\begin{abstract}
Atractus badius has a long and controversial nomenclatural history due to both its antiquity and the brevity of its original description. This species was described based on two syntypes from Java. Later, a lectotype was designated and the distribution range restricted to the Guiana Shield. Although this species has been repeatedly recorded throughout Amazonia and the Andes, these records have been erroneously assigned to $A$. badius because of a considerable level of confusion in the literature. We found 13 additional specimens of this poorly known snake, expanding our knowledge on its morphological variability, phylogenetic relationships and distribution. In this paper, we report new localities and data on meristic, morphometric, coloration, scales micro-ornamentation, osteology and hemipenial morphology to A. badius. We also determine the phylogenetic position of $A$. badius as nested in a composite Guiana Shield clade. In addition, we discuss recent advances on the systematics of Atractus and comment on some 'new arrangements' with respect to previously recognized species groups and available morphological evidence. Finally, we highlight the importance of accurate voucher identification before promoting taxonomic changes or implementing nomenclatural acts derived from new phylogenetic hypotheses, and notably propose the synonymy of the recently described $A$. pyroni with A. roulei.
\end{abstract}

Key words: Hemipenial morphology, integrative taxonomy, microdermatoglyphics, molecular phylogeny, osteology, sequence voucher misidentification.

\section{INTRODUCTION}

The cryptozoic snakes of the genus Atractus Wagler, 1828 are distributed widely in the New World, occurring from Panama to Argentina (Giraudo \& Scrocchi 2000, Myers 2003). Atractus is the most species-rich snake genus in the world, encompassing 147 valid species to date (Passos et al. 2019a, b, Uetz et al. 2021). Despite a substantial number of taxa originally known from small series with restricted distributions, several species have been recently rediscovered in the wild or reported based on old misidentified material (sometimes for decades) stored in collections (Köhler \& Kieckbusch 2014, Passos et al. 2018a). In the last ten years, the taxonomy of Atractus has undergone an unprecedented flux of improvements based on detailed morphological studies (see Passos et al. 2017, 2018b). As an expected result, the taxonomy of several species complexes has been enhanced regarding species delimitation and morphological variation (Passos et al. 2010, 2019a, Passos \& Prudente 2012, Melo-Sampaio et al. 2019, 2021). However, other taxonomic assemblages within the genus still need 
further study to accurately characterize species boundaries and phylogenetic relationships.

In parallel, new phylogenetic hypotheses derived from molecular datasets have much improved our knowledge about the relationships among species and clades within Atractus (Zaher et al. 2009, Grazziotin et al. 2012, Pyron et al. 2013, Figueroa et al. 2016, Arteaga et al. 2017). However, these analyses are misleading because they are based both on several misidentified voucher specimens and/or chimeras created between distinct and non-closely related species
(Passos et al. 2017; Table I). Such identification problems may be overcome by simple efforts toward the examination of the corresponding voucher specimens. Many recent reviews provide unambiguous diagnoses and detailed comparative data for taxa distributed along South American provinces (Passos et al. 2009a, b, 2010, 2013a), with sequences for autochthonous species available in GenBank. As for recent voucher specimens (Table I), they should be accurately identified by direct examination or reference to relevant literature.

Table I. Re-identification of Atractus sequences available in GenBank based on direct examination of voucher specimens until September 2019. The specimens followed with "*" are correctly identified in GenBank but are misidentified in Arteaga et al. (2017). The total number of doubtful identifications can be obtained by adding the specimens marked with "*" and those written in bold in the re-identification column. The specimen referred to as GFM 307 "." correspond to MPEG 21582, and ANF 2390t correspond to MZUTI 5409.

\begin{tabular}{|c|c|c|c|}
\hline Voucher specimen & Number of sequences & Previous ID & Re-identification \\
\hline MZUTI 4330 & 3 & A. cerberus & A. cf. iridescens \\
\hline MZUTI 2650 & 3 & A. dunni* & A. dunni \\
\hline MZUTI 3758 & 2 & A. esepe* & A. cf. iridescens \\
\hline MZUTI 3758 & 1 & A. iridescens* & A. iridescens \\
\hline MZUTI 3759 & 3 & A. iridescens* & A. iridescens \\
\hline MZUTI 4178 & 3 & A. iridescens* & A. iridescens \\
\hline MZUTI 4122 & 3 & A. iridescens* & A. iridescens \\
\hline DHMECN 7644 & 3 & A. lehmanni & A. roulei \\
\hline MZUTI 5109 & 3 & A. microrhynchus & A. dunni \\
\hline MZUTI 1385 & 3 & A. occidentalis & A. dunni \\
\hline MZUTI 2649 & 3 & A. occidentalis & A. dunni \\
\hline MZUTI 3323 & 3 & A. occidentalis & A. dunni \\
\hline MZUTI 5107 & 3 & A. pyroni & A. roulei \\
\hline GFM 307. & 3 & A. schach & A. snethlageae \\
\hline MZUTI 4178 & 2 & Atractus sp.* & A. iridescens \\
\hline ANF $2390+$ & 3 & A. touzeti & Atractus pachacamac \\
\hline IBSP 71932 & 2 & A. zebrinus & A. triherurus \\
\hline TOTAL & $53 / 155(29 \%)$ & 13/32 spp. & 8/24 spp. \\
\hline
\end{tabular}


In this paper, we report new material unambiguously assigned to Atractus badius and provide new data on variation for distinct and putatively independent morphological systems (e.g., scales, bones and male genitalia). We also infer the phylogenetic position of A. badius based on previously available sequences and new ones obtained from examined voucher-based specimens ensuring accurate identifications.

\section{HISTORICAL RÉSUMÉ}

Atractus badius has a long and controversial nomenclatural history due to both its antiquity and brevity of its original description. Friederich Boie recognized the species early in the XIX Century based on an unpublished manuscript entitled 'Erpétologie de Java'. Later, his brother H. Boie (1827) published such study describing Brachyorrhos badius together with B. flammigerus, B. schach and B. torquatum (see Hoogmoed 1980 for more details on its nomenclatural history). Wagler (1828) erected the genus Atractus to accommodate a new species A. trilineatus. Later, Wagler (1830) proposed the synonymy of Brachyorrhos Kuhl with Atractus, recognizing $B$. badius under the name Atractus badius. Duméril et al. (1854) proposed the genus Rabdosoma and used a new combination, $R$. badium. The same authors included $B$. flammigerus and $B$. schach as junior synonyms of $R$. badium, but recognized $R$. torquatum as a distinct species (see Passos \& Prudente 2012 for additional details). Günther (1858) reported on two specimens of " $R$. badius" from Pará, remarking the white-banded pattern among them. Jan (1862) recognized other species outside the Guiana Shield as "varieties" of Rabdosoma badium (e.g., R. badium var. multicintum from Peru; see Passos et al. 2009b). Boulenger (1894) proposed the synonymy of Rabdosoma with Atractus, but still recognized Atractus badius as a widespread and polytypical taxon. After Boulenger, the name A. badius has been incorrectly applied to several Atractus species that occur both in Amazonia and the Andes. Virtually all authors prior to Hoogmoed (1980), associated this name to several specimens or species with 17 dorsal scale rows and a dorsal coloration with dark alternate bands or blotches on the back. This was likely also reinforced, in part, by the seminal work of Savage (1960), in which the definition of the Atractus badius species group may have influenced subsequent species' identification. This scenario with a generalized definition of $A$. badius remained until Hoogmoed (1980) rediscovered the syntypes of A. badius, A. flammigerus and A. schach. He established the distinctive nature of the latter two species and removed them from synonymy of A. badius. Hoogmoed (1980) redescribed A. badius, designated a lectotype, and transferred A. mitcheli and A. subcinctum to the synonymy of A. badius and further emphasized that, "it is very likely that this presumed species (= A. badius) does not have such an extensive distribution and that it is composed of several species. To be able to make conclusive statements on this subject a revision of all South American material referred to this species would be necessary." Even after Hoogmoed's comprehensive review, Atractus badius continued to be inadvertently associated with many species outside the Guiana Shield without any justification (Peters \& OrejasMiranda 1986, Pérez-Santos \& Moreno 1988, Carrillo \& Icochea 1995). More recently, Ávila-Pires et al. (2010) reported on the second vouchered specimen of $A$. badius from the Brazilian part of the Guiana Shield (see Hoogmoed 1980 for the additional Brazilian record to Amapá) to ESEC Grão Pará, state of Pará. All the specimens outside the Guiana Shield previously reported in the literature as A. badius (sensu Hoogmoed 1980) 
refer in fact to the A. schach or A. snethlageae species complexes which have undergone recent reviews (Melo-Sampaio et al. 2019, 2021). Finally, despite Savage's early definition of the Atractus badius species group, no other species was later associated to that group, presumably because of the lack of detailed descriptions and comparisons.

\section{MATERIALS AND METHODS}

\section{Material and techniques for morphological characters}

Institutional acronyms are as listed in Sabaj (2020). All specimens of $A$. badius examined by us are listed in Appendix I. Terminology for cephalic shields follow Savage (1960), whereas ventral and subcaudal counts follow Dowling (1951). Measurements were taken with a dial caliper to the nearest $0.1 \mathrm{~mm}$, except for snoutvent length (SVL) and tail length (TL), which were measured with a ruler to the nearest $1 \mathrm{~mm}$. Sex was determined by presence/absence of hemipenes after a ventral incision at the base of the tail. We examined maxillae of all specimens under a stereoscope, through a narrow lateromedial incision between the supralabials and the maxillary arch. After removing tissues covering the maxillary bone, we counted teeth and empty sockets. Terminology for microornamentation descriptions follows Price (1982) and Price \& Kelly (1989), with a few modifications. The superficial layer of the dorsal scales was sampled from the middorsal body region of nine individuals of Atractus badius. We removed scale layers (= Oberhäutchen) with forceps and stored them separately in $70 \%$ ethyl alcohol. The layers were affixed to metal plates with doublefaced carbon tape, then metallized using a Denton Vacuum Desk IV Metallizer. They were photographed using a JEOL JSM 6390LV Scanning Electron Microscope (SEM) under 500-10.000x magnification and 10-20 kV at the Scanning Electron Microscopy laboratory of the Museu
Nacional/UFRJ. As first stated by Price \& Kelly (1989), different microdermatoglyphics might occur in basal and apical portions of scales. Thus, we describe both scale portions for $A$. badius (MNRJ 26712 and USNM 438). Terminology for description of skull osteology follows Cundall \& Irish (2008). The head of one individual (MNRJ 26712) was scanned on a Skyscan 1173 invivo high-resolution $\mu$-CT scan at the Nuclear Instrumentation laboratory COPPE/UFRJ. The specimen was scanned at $50 \mathrm{kV}$ and $160 \mu \mathrm{A}$ and rendered in three dimensions using CTVox for Windows 64 bits version 2.6. Terminology for hemipenial descriptions follows Zaher (1999) with a few minor adaptations based on Passos et al. (2013b). The method for preparation of preserved hemipenes was modified from Pesantes (1994) in replacing $\mathrm{KOH}$ with distilled water according to Passos et al. (2016). Prior to the inflation with petroleum jelly, the organs were placed in an ethyl alcohol (70\%) solution with Alizarin red for 15-20 min in order to stain the ornamented calcareous structures according to adaptations from original procedures used by Uzzell (1973).

\section{Molecular sampling, techniques, species identification and selection of sequences}

We obtained tissue samples from 36 individuals representing 12 nominal species, comprising new sequences for the following species: Atractus badius, A. carrioni, A. elaps, A. favae, A. flammigerus, A. gigas, A. latifrons, A. major, A. riveroi, $A$. roulei, $A$. torquatus and $A$. trilineatus. The new samples were acquired through field sampling, loans and donations. Newly sequenced vouchers produced in this study are listed in Table II.

We extracted mitochondrial and nuclear DNA from tissue samples of liver stored in absolute ethanol, using a guanidinium isothiocyanate extraction protocol. Polymerase Chain Reaction (PCR) amplification of gene fragments was performed in a final volume of $24 \mu \mathrm{l}$ reactions 
Table II. Specimens of Atractus sequenced in this work with Genbank accession numbers.

\begin{tabular}{|c|c|c|c|c|}
\hline SPECIES & VOUCHER & $16 S$ & CYTB & ND4 \\
\hline Atractus badius & AF1558 & MH790471 & MK835884 & \\
\hline Atractus badius & MNRJ 26710 & & MK835885 & \\
\hline Atractus badius & MNRJ 26711 & & MK835886 & \\
\hline Atractus badius & MNRJ 26712 & MH790472 & MK835887 & \\
\hline Atractus badius & MNRJ 26714 & MH790474 & MK835888 & \\
\hline Atractus badius & MNRJ 26715 & MH790475 & MK835889 & \\
\hline Atractus badius & MNRJ 26716 & & MK835890 & \\
\hline Atractus badius & MNRJ 26717 & MH790476 & MK835891 & \\
\hline Atractus badius & MNRJ 26718 & MH790477 & MK835892 & \\
\hline Atractus carrioni & QCAZ 6446 & MT507867 & & MT511983 \\
\hline Atractus carrioni & QCAZ 6533 & MT507868 & & MT511984 \\
\hline Atractus carrioni & QCAZ 6534 & MT507869 & & MT511985 \\
\hline Atractus carrioni & QCAZ 10038 & MT507864 & MT511977 & MT511982 \\
\hline Atractus carrioni & QCAZ 13094 & MT507865 & MT511978 & \\
\hline Atractus carrioni & QCAZ 13874 & MT507866 & & \\
\hline Atractus favae & MZUSP 20211 & MT507870 & MT511979 & \\
\hline Atractus flammigerus & MNRJ 26719 & MH790487 & & MK835931 \\
\hline Atractus flammigerus & MNRJ 26720 & MH790488 & MK835903 & MK835932 \\
\hline Atractus latifrons & MPEG 22630 & MH790493 & MK835908 & MT511986 \\
\hline Atractus latifrons & MPEG 24590 & & MK835909 & MT511987 \\
\hline Atractus latifrons & UFMT-R 7630 & MH790496 & & \\
\hline Atractus riveroi & MNRJ 26087 & MH790526 & MK835916 & \\
\hline Atractus roulei & QCAZ 4503 & & KY610090 & KY610116 \\
\hline Atractus roulei & QCAZ 4544 & KY610069 & KY610091 & KY610117 \\
\hline Atractus roulei & QCAZ 6256 & & & MT511988 \\
\hline Atractus roulei & QCAZ 7192 & MT507871 & MT511980 & \\
\hline Atractus roulei & QCAZ 7887 & MT507872 & & MT511989 \\
\hline Atractus roulei & QCAZ 7888 & MT507873 & & \\
\hline Atractus roulei & QCAZ 7889 & MT507874 & & MT511990 \\
\hline Atractus roulei & QCAZ 9643 & MT507875 & MT511981 & MT511991 \\
\hline Atractus roulei & QCAZ 9652 & MT507876 & & MT511992 \\
\hline Atractus torquatus & AF 2281 & MH790530 & MK835920 & MK835939 \\
\hline Atractus torquatus & MPEG 23686 & MH790532 & MK835921 & MK835941 \\
\hline Atractus torquatus & MTR 19069 & MH790533 & MK835922 & \\
\hline
\end{tabular}


using 1X PCR Buffer (-Mg), 3 mM MgCl2, 0.2 mM dNTP mix, $0.2 \mu \mathrm{M}$ of each primer, $0.1 \mathrm{U} / \mu \mathrm{l}$ of Taq DNA Polymerase and $1.5 \mu \mathrm{l}$ of extracted DNA. PCR products were analyzed on $1 \%$ agarose gels by horizontal electrophoresis (the target fragment size was estimated from molecular weight markers), using SYBR1 Safe (Invitrogen, Carlsbad, CA) staining, and analyzed with a Molecular Imager1 Gel DocTM XR+ Imaging System (Bio Rad, Hercules, CA). Amplified products were treated with ExoSAP-IT (Affymetrix, Cleveland, $\mathrm{OH}$ ) to remove remaining dNTPS and primers, and extraneous single-stranded DNA produced in the PCR. Macrogen Inc. performed double stranded sequencing of the PCR products in both directions. The mitochondrial genes 16S, CYT-B, and CMOS were amplified using the same procedures and primers described in Arteaga et al. (2017), whereas $12 S$ followed those of Zaher et al. (2009). We also obtained sequences of NADH4 [ND413824H and ND412931L (Blair et al. 2009)], NT3 [NT3-F3 and NT3-R4 (Kendall et al. 2000)] and RAG1 [RAG1-MartF1 and RAG1-AmpR1 (Hoegg et al. 2004)]. In addition, we included GenBank sequences for 42 terminals, limiting the sampling only to specimens checked for identification, except for two (DHMECN 10179 and KU 214837). However, in all cases we confirmed previous identifications by examination of digital photographs. We assigned specimen DHMECN 5105 tentatively as Atractus ecuadoriensis due to its proximity to the type-locality and because this species is still known only from its typeseries. Unfortunately, this specimen was not available for examination by us. Based on first hand examination, we re-identified several terminals from previously published datasets. We excluded sequences for which we couldn't trace the voucher, provenance or both, and separated the previously chimeras found in Grazziotin et al. (2012), Pyron et al. $(2015,2016)$ and Arteaga et al. (2017).

\section{Edition, alignment, evolution model and phylogenetic analyses}

All amplified loci were obtained from single voucher specimens to avoid "chimeric terminals" (terminals including sequences taken from distinct individuals representing different species). Data were assembled and aligned in Mega 7.0 (Kumar et al. 2016) under default settings for the alignment program Clustal $W$ (Thompson et al. 1994) and trimmed at both ends. The best-fit nucleotide substitution models and partitioning scheme were determined simultaneously using PartitionFinder 2 (Lanfear et al. 2016) under the Bayesian Information Criterion (Sullivan \& Joyce 2005). We built a concatenated matrix in SequenceMatrix (Vaidya et al. 2011). We employed the Bayesian inference (BI) method to obtain the optimal tree topology of the combined, partitioned dataset using MrBayes v3.2.1 (Ronquist et al. 2012). All parameters except topology and branch lengths were unlinked between partitions. Four independent runs, each with four MCMC chains, were ran for 20 millions generations, sampled every 10,000 generations. We used Tracer v1.6 (available from http://beast.bio.ed.ac.uk/ Tracer) to assess convergence and stationarity to ensure effective sample sizes (ESS) >200 of model parameters. We combined runs using LogCombiner 1.8 after discarding the first 10\% of generations as burn-in and summarized them in a maximum clade credibility tree in TreeAnnotator v1.8.3 (Drummond et al. 2012). We also performed Maximum likelihood (ML) analyses on the partitioned dataset using RAXML (Stamatakis 2014), under GTRCAT approximation. Support of nodes was assessed using the rapid-bootstrapping algorithm with 1000 nonparametric bootstraps. We edited and visualized the phylogenetic trees using FigTree v1.4.2 (available in http://tree.bio.ed.ac.uk/software/ figtree/). We consider the clades with posterior 
probabilities values above $>95 \%$ and bootstrap values $>70 \%$ as strongly supported.

\section{RESULTS}

\section{Phylogenetic analyses}

The results from both $\mathrm{BI}$ and $\mathrm{ML}$ analyses are overall very similar (Fig. 1). We recovered a
Guiana Shield clade, maximally supported (A highlighted in green), containing $A$. torquatus sister to A. flammigerus + A. riveroi. This clade is sister to moderately supported clade $B$ (highlighted in pink), which includes two sister clades, (Atractus duboisi, (A. resplendens, A ecuadorensis)) and (A. pachacamac, (A. dapsilis, (A. trefauti, A. schach))), each strongly supported.

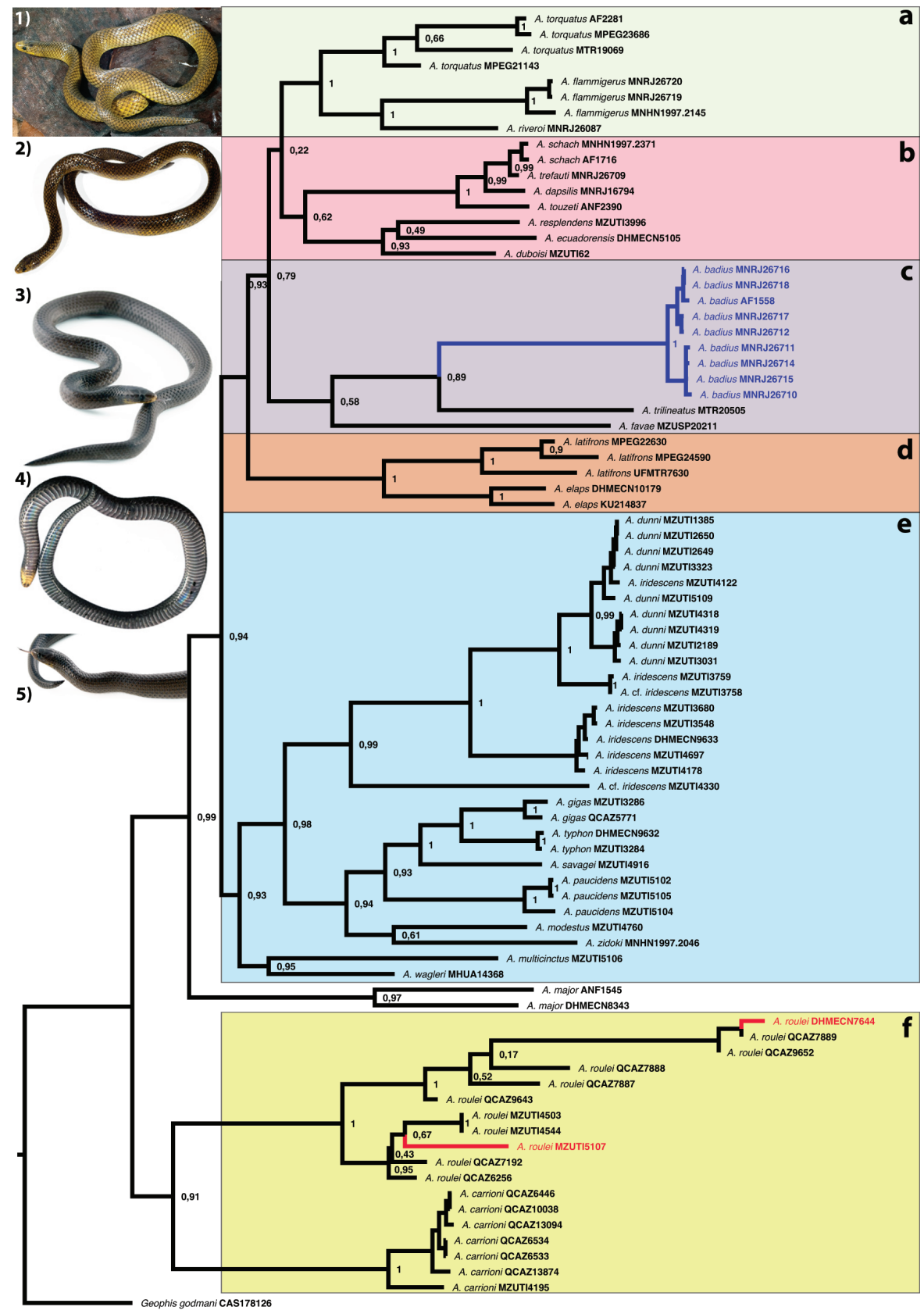

a Figure 1. Phylogenetic relationships of Atractus estimated under a Bayesian Inference. Posterior probabilities are show next to nodes. Colored boxes delimit clades (a-f) discussed in the text. Images on the left margin illustrate the color variability of Atractus roulei and the specimens acronym and location are as follow, respectively: 1-2) QCAZ 7789 and QCAZ 7887, respectively, both specimens from Guanazán and 3-5) QCAZ 9652 from Zaruma, both in the Province of El Oro, Ecuador. Photos were taken by Luis A. Coloma and OTC, and are available at BioWeb.bio. 
Clade B's moderate support was probably due to lacking other species from the Colombian Andes, the region with larger concentration of Atractus species (Passos et al. 2009a). Some new terminals are being added to Atractus phylogeny in the course of studies with different focuses and goals (e.g., Melo-Sampaio et al. (2021)). Clades $A$ and $B$ are sister to the poorly supported clade C (A. favae, (A. trilineatus, A. badius)). Similarly, the lacking of other species of the Atractus collaris species group probably influenced the topology recovered here (see Passos et al. 2018b), and such taxa should be added ongoing works. We recovered a maximally supported Atractus elaps group (D - highlighted in orange) as sister to (C, $(A, B))$.

As sister to the set of clades described above, we recovered a strongly supported transAndean clade ( $E$, highlighted in blue). A clade containing paraphyletic species A. dunni and $A$. iridescens (A. iridescens group sensu Arteaga et al. 2017) is sister to the strongly supported ((A. zidoki, A. modestus), (A. paucidens, (A. savagei, (A. typhon, A. gigas)))). These two clades are sister to (A. wagleri, A. multicinctus). We refrain from making an imprudent taxonomic decision regarding the Atractus iridescens group (sensu Arteaga et al. 2017) and recommend including more genes and morphological systems in order to shed some light on its taxonomy.

The Amazonian species A. major is sister to the set of clades described above. Together they are sister to the strongly supported transAndean clade (A. carrioni, A. roulei), herein named Clade $F$ (highlighted in yellow), which corresponds to the $A$. roulei group (Passos et al. 2013b). Two specimens of A. roulei within this clade correspond to specimens identified by Arteaga et al. (2017); one was referred to as A. lehmanni, whereas the other was (the only specimen) used to describe A. pyroni (see taxonomic section and discussion below).

\section{Morphology}

Updated diagnosis: Atractus badius can be distinguished from all congeners by unique combination of the following characters: (1) smooth dorsal scale rows $17 / 17 / 17$; (2) postoculars two; (3) loreal moderately long; (4) temporals 1+2; (5) supralabials seven, third and fourth contacting eye; (6) infralabials seven, first three contacting chinshields; (7) maxillary teeth usually six; (8) gular scale rows three; (9) preventrals three; (10) ventrals 146-160 in females, 138-155 in males; (11) subcaudals 33-50 in females, 40-47 in males; (12) dorsal coloration with black dyads separated by cream bands, usually in a red or dark gray background; (13) ventral coloration immaculate cream anteriorly and with squared black spots from mid-belly to tail; (14) body size moderately long in females (maximum $390 \mathrm{~mm}$ SVL) and males (maximum $360 \mathrm{~mm} \mathrm{SVL}$ ); (15) tail moderately long in females (12.3-16.6\% of SVL) and long in males (14.3-20.3\% of SVL); (16) hemipenis moderately bilobed, almost fully bicapitated and bicalyculated.

Color pattern after preservation $(n=8)$ : Dorsum of head uniformly black from snout to posterior margin of parietals (= cephaliccap); white band (2-3 scales long) covering the occipital and temporal regions between cephalic-cap and first body dyad; white temporal band usually with triangular descending shape and sometimes interrupted on level of posterior parietal suture by a connection between black cephalic-cap and first body dyad; head laterally black including supralabials, except for white spots (diagonally arranged) covering anterior portion of supralabials among its sutures; seventh supralabial usually part of white temporal band, except in melanic specimens, in which the white pigment is restricted to the anterior portions of supralabials and infralabials near the sutures of each scale; symphysial, first four to six infralabials and almost all portions 
of chinshields dark brown to black, with some creamish white pigment; mid-posterior portion of chinshields, gulars and preventrals uniformly whitish cream; belly whitish cream with black spots or blotches concentrated on the lateral edges of ventral scales or on the middle of the body; first third of body with a few dark brown to black squared spots or small checkered bars; dark marks most concentrated on the terminal third of body, mainly after midbody region; usually squared spots arranged linearly on the midline resembling conspicuous longitudinal stripes; black spots often laterally concentrated on the posterior region of body; melanic specimens frequently present ventral marks restricted to lateral margins of ventral scales, giving an impression of ventral invasion of black pigment from dorsal dyads; ventral surface of tail with high concentration of brown or black irregular dots, with cream pigment on the margins of the subcaudals; sometimes median suture of subcaudals predominantly cream in melanic specimens; dorsum of body reddish brown with black dyads (three to four scales long) separated by cream band (1-2 scales long); interspaces between the dyads (4-6 scales long), with black pigment concentrated on the posterior portion of each scale; interspaces usually shorter than dyads; frequently, posterior dyads of body completely darkened with brown to black pigment, similar to background color.

Color pattern in life $(n=6)$ : Cephaliccap uniformly black; temporal and occipital regions white except in melanistic specimens; supralabials and infralabials black with white pigment restricted to anterior regions of scales near sutures; gular region creamish white with black spots or dots; dorsum of body red, covered by large black dyads separated by narrow white rings; belly cream scattered with squared dark brown to black blotches, dots and spots; ventral surface of tail mostly dark brown to black with a few cream spots (Fig. 2).

Microdermatoglyphics $(n=2)$ : Basal portion of dorsal scales with lamellate and imbricate cells caudally oriented; cell borders 5-6 $\mu \mathrm{m}$ distant from each other, with small and slightly triangulated denticulations, higher than wide and rarely exceeding $0.5 \mu \mathrm{m}$; microornamentation on the cell surface composed by small and inconspicuous pores. On the apical portion, cells are lamellate and overlapping; cell borders with long and narrow spinulated denticulations (2-3 $\mu \mathrm{m}$ high) that seem to be embedded in the adjacent cell and are also caudally oriented (Fig. 3).

Skull osteology $(n=1)$ : Cranium with colubroid structure; skull height, in lateral view, slightly increases toward end of parietal and decreases towards exoccipitals. Premaxilla: slightly triangular anteriorly with concave lateral edges expanding dorsally; ascendant process of premaxilla expands posteriorly, contacting vertical lamina of nasal and anterior-medial edge of nasals; nasal process absent; laterally, transverse process expands towards maxilla; ventrally, premaxilla expands posteriorly, forming short vomerian process, which contacts anterior-ventral tip of septomaxilla. Septomaxillae: located between nasals and vomers, forming floor of nasal cavity; its anteriordorsal edge fits posterior portion of ascendant process of premaxilla; septomaxillae lateraldorsally projected, comprising short conchal process, approximately trapezoidal without contact with nasals or prefrontals; septomaxillae posteriorly attached to frontals, forming prokinetic joint, and dorsal contact with vertical lamina of nasals. Vomers: premaxillary process slightly expanded anteriorly, delimiting anterior edge of olfactory capsule; premaxillary processes contact each other and septomaxillae dorsally; caudal processes of vomer expanded 


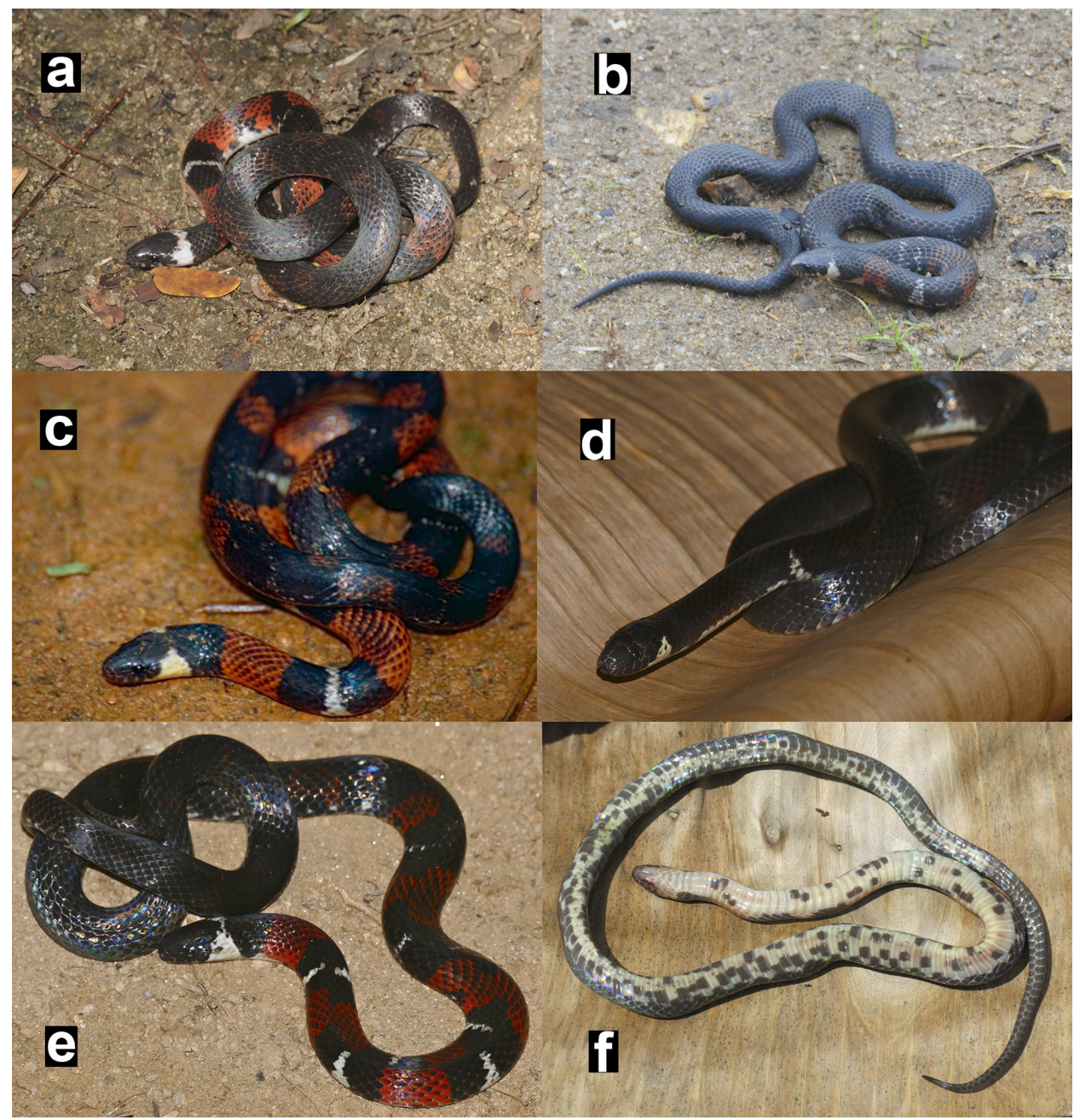

Figure 2. General view in life of the body of Atractus badius, showing banded coralcolor pattern (a-c, e), specimen entirely melanic (d), and ventral view (f). Photos by Bernard Dupont (c, d, e) and Fausto Starace $(a$, b, f). posterior-medially, constituting exochoanal fenestra. Nasals: trapezoidal, located between premaxilla and frontals, covering nasal cavity dorsally; nasal septum situated vertically between nasals, forming inner wall of nasal cavity; dorsal edges convex; anterior-medial edges contact ascendant process of premaxilla; nasals do not compose prokinetic joint; small process originated on posterior-lateral edge contact prefrontal; vertical lamina contact ventrally middorsal surface of septomaxilla. Frontals: trapezoidal, in dorsal view, located anterior-medially, contributing to dorsal roof and covering ventral and lateral edges of neurocranium; laterally, it forms dorsal edge and inner wall of eye socket; frontals contacting prefrontals anterior-laterally, parietal posteriorly, and postorbital posterior-laterally; frontals ventrally expanded anteriorly into septomaxillary process, contacting septomaxilla at prokinetic joint; orbital lamina descending and converging medially, comprising narrow subolfactory process, resting on medial keel of parabasisphenoid. Parietal: pentagonal, in dorsal view, with concave anterior edge attached to frontals; small anterior-lateral projections articulating with postorbital bone and, exceeding its lateral limits; posteriorly, parietal sutured to supraoccipital, posterior-laterally to prootics and ventral-medially to parabasisphenoid; dorsal surface of parietal smooth with two parietal crests, converging posteriorly reaching 


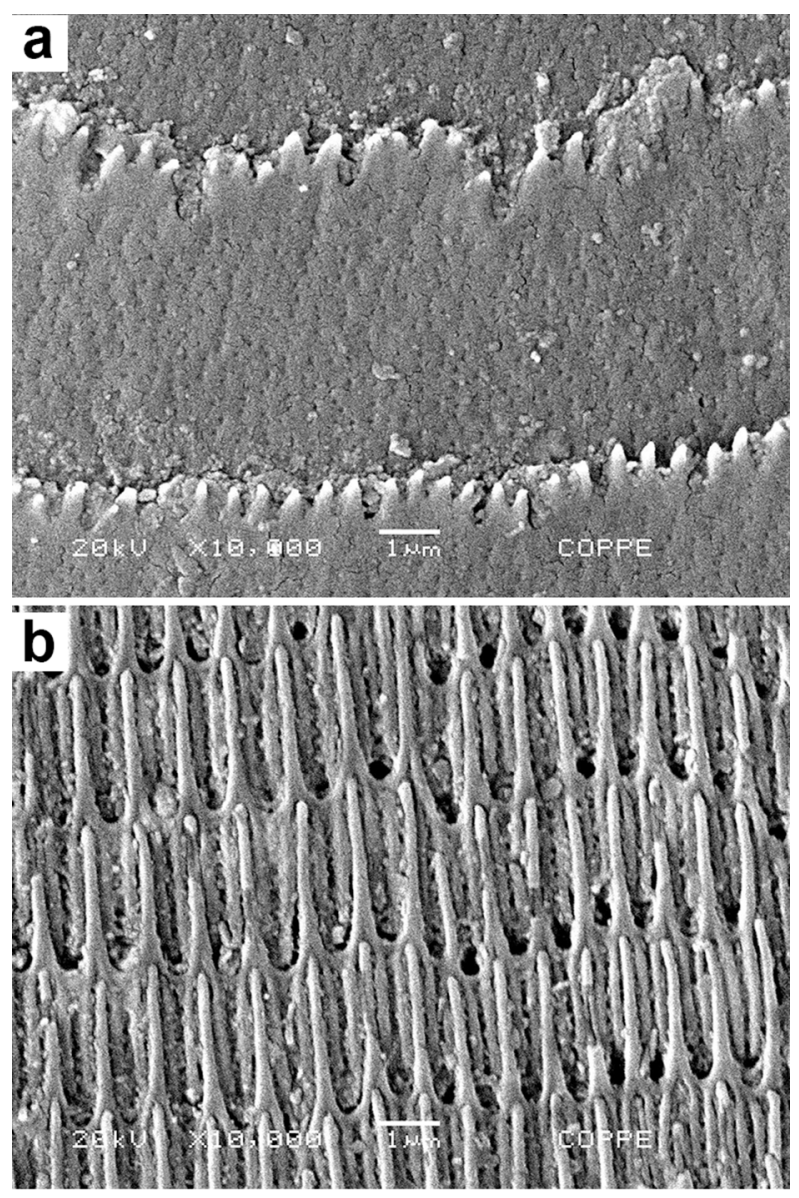

Figure 3. Micro-ornamentation patterns under $\times 10.000$ magnifications on basal (a) and apical (b) portions of dorsal scales of Atractus badius (USNM 438). Scales bar $=1 \mu \mathrm{m}$.

anterior edge of supraoccipital. Supraoccipital: fused, pentagonal, located on posterior-dorsal region of skull; supraoccipital contacting parietal anteriorly, prootics anterior-laterally, and exoccipitals posteriorly; anterior edge of supraoccipital concave; lateral margins do not contact supratemporal; dorsally, supraoccipital with oblique crest, which makes its posterior portion ventrally positioned. Exoccipitals: trapezoidal, in dorsal view, and located on posterior edge of skull, comprising dorsal edge of foramen magnum; each exoccipital contacting basioccipital ventrally and prootic laterally; two foramina lateral-ventrally located on each exoccipital, posteriors to foramen ovale.
Basioccipital: pentagonal and located on posterior-ventral portion of braincase; basioccipital contributing to posterior portion of braincase floor and median portion of occipital condyle; basioccipital contacts parabasisphenoid complex anteriorly, prootics and exoccipitals laterally, and atlas posteriorly, where it composes ventral edge of foramen magnum. Parabasisphenoid: triangular and located midventrally, contacting frontals anteriordorsally, parietal and prootic laterally, and basioccipital posteriorly; parabasisphenoid with two lateral-ventrally foramina. Prootics: irregular, contacting parietal dorsally and anteriorlaterally, parabasisphenoid and basioccipital ventrally, supraoccipital posterior-dorsally, exoccipital posterior-laterally; anterior portion of supratemporal lies on its dorsal surface; each prootic pierced by two foramina at ventrolateral surface; posterior region of prootics with small enlargement, comprising foramen ovale. Columela auris: small and slender, inserted on foramen ovale, composed by posterior-lateral portion of prootics and anterior-lateral portion of exocciptals; columela auris crosses foramen ovale towards process located on medial portion of quadrate. Prefrontals: irregular, contacting frontal on its latera-posterior region and ventrally maxilla and palatine; lateral descending lamina of prefrontal enlarged dorsally; ventrally, prefrontal with enlarged process supported by palatine; anterior lamina concave with medial process towards prokinetic joint pierced by lacrimal foramen, which crosses prefrontal ventrally. Postorbitals: small, slender with " $\mathrm{C}$ " shape, delimiting orbital cavity posteriorly; dorsal portion in contact with anterior-lateral process of parietal and, on its anterior tip, contacting slightly posterior-lateral portion of frontal. Maxillae: curved, limiting lateral edge of anterior portion of skull; maxilla, in lateral view, extends from anterior tip of nasals to posterior 
portion of frontals; posterior tip of maxilla attached to anterior tip of ectopterygoid; two medial processes: palatine on medial portion contact dorsally prefrontal; and ectopterygoid on posterior portion contacting ectopterygoid; lateral surface of maxillary concave and pierced by single foramen; maxillary teeth 6-7 posteriorly curved and decreasing in size. Palatines: slightly shorter than maxillaries, in anterior-dorsal contact with prefrontal; posterior tip slightly forked and attached ventrally to anterior-dorsal tip of pterygoid; maxillary process of palatine located laterally, do not contact palatine process of maxilla, and supporting ventral portion of prefrontal dorsally; palatine with longitudinal row of five to six teeth; choanal process absent. Pterygoids: located posterior to palatine and its posterior end exceeding posterior limits of skull; peterygoids with longitudinal row of 12 teeth, smaller and reducing in size posteriorly; ectopterygoid fits to dorsal surface of pterygoid approximately on the level of gap between fifth and sixth teeth, extending third teeth. Ectopterygoids: elongated, connecting maxilla to pterygoid; anterior portion bifurcated and attached to ectopterygoid process of maxilla, exceeding maxillary row of teeth and reaching sixth to seventh teeth; ventrally attached to dorsal-medial portion of pterygoid. Supratemporals: narrow and elongated bones placed lateral-posteriorly to braincase, ventrally attached to posterior portion of prootics and posteriorly reaching posterior portion of exoccipitals; posterior-dorsal contact with quadrate. Quadrates: elongated and vertically positioned bones, located on posterior portion of skull and laterally angulated; proximal portion enlarged, medially articulated with posteriordorsal portion of supratemporal; distal end slightly enlarged, articulating with glenoid cavity of retroarticular process of mandible, forming quadrate-articular articulation; lateral lamina twined, facing to posterior portion of skull and with short medial process. Compound bone: elongated bone comprised by surangular, articular crests and retroarticular process (2/3 mandibular length); compound bone is positioned at posterior end of mandible, connected to skull through glenoid cavity on its posterior end; anterior portion projected as tapering process, which inserts into dentary and extends until level between sixth and seventh teeth of dentary; lateral lamina of compound bone concave, and its midventral portion contacts angular; mandibular fossa relatively deep, with anterior foramen located on $1 / 3$ of bone, composed by surangular crest laterally and prearticular crest medially; prearticular crest slightly higher than surangular; anteriorlateral portion with foramen on each bone; retroarticular process short and rounded, medially curved. Dentaries: located at anterior portion of mandible, each curving medially on its anterior end towards opposite dentary; longitudinal row of eight teeth posteriorly curved and reducing gradually in size; lateralposteriorly inserting to compound bone on its forked portion; anterior end of compound bone fits into these processes, reaching level of sixth tooth; mentonian foramen located laterally at level of fifth tooth; midposterior end of dentary contacts anterior tip of angular and anterior half of splenial; Meckel's groove opening at fourth tooth level and extending posteriorly through whole dentary. Splenials: narrow and short bones, located on medial surface of mandible, with mesoventral orientation with respect to articulation between dentary and angular; anterior portion fits into dentary through tapering process, reaching gap between fourth and fifth tooth, and its posterior end attached to angular; posterior region of splenial pierced by mylohyoid foramen. Angulars: triangular and located on medial surface of 
mandible, with tapering projection directed posteriorly and anterior-dorsal process extending above splenial, reaching posteriordorsal tip of dentary dorsally; dorsal process of angular originates at level of seventh tooth; anterior-ventral portion of angular pierced by mylohyoid foramen (Fig. 4).

Hemipenial morphology ( $n=3)$ : Organ in situ (retracted) extends at level of $8-10^{\text {th }}$ subcaudal and bifurcates at level of $5-6^{\text {th }}$ subcaudal. Fully everted and maximally expanded hemipenis bilobed, almost bicapitated and bicalyculated (sensu Zaher 1999); lobular region equivalent (based on previously semi-everted organs), or slightly wider than hemipenial body; lobes attenuated and centrifugally oriented with a distinct " $V$ " orientation, only fully developed on the previously inverted organs (Fig. 5b, e); lobes symmetrical or asymmetrical (Fig. 5a, d) with right lobe slightly longer than left one; lobes covered with spinulate calyces; spinules replaced by regular papillae toward apices of lobes; basal region of each lobe with a welldefined capitular groove on asulcate and lateral sides; capitular groove indistinct on the sulcate side; capitulum with regular rows of papillae on lobes and intrasulcar region; intrasulcar region on the sulcate side of organ covered with irregularly distributed small size spines; hemipenial body elliptical (Fig. 5a, d) or triangular (Fig. 5b, e) and slightly longer than capitulum; hemipenial body ornamented with hocked spines ranging from moderate to large size; larger spines distributed along both sides of organ, except for the most basal portion of hemipenis; hooked spines sometimes with laterally expanded basis on both sides of organ; sulcus spermaticus bifurcating basally and extending for about $30 \%$ of organ length; sulcus spermaticus bifurcation occurring much earlier from capitular groove on the proximal region of hemipenial body with (Fig. 5e-f) or without (Fig. 5d) spines; each branch of sulcus spermaticus centrolinearly oriented, running to tip of lobes; sulcus spermaticus margins relatively thick at level of division and laterally expanded on capitular region; sulcus spermaticus not bordered by spinules; most proximal region of hemipenial body poorly ornamented, covered with a few spines (Fig. 5e), spinules (Fig. 5d) or longitudinal plicae (Fig. 5f); naked pocket shallow, extending laterally (right side) from most basal region to length of hemipenial body.

Distribution ( $n=13$ ): Atractus badius occurs along the lowland evergreen forest of the eastern part of the Guiana Shield at elevations between 10-300 meters above sea level. This species has been recorded to date in northern Pará and Amapá States, Brazil (Hoogmoed 1980, ÁvilaPires et al. 2010), French Guiana (Hoogmoed \& Ávila-Pires 1991, Abuys 1983, Chippaux 1986, Starace 1998) and Suriname (Hoogmoed 1980). We report here eight additional localities of Atractus badius (Fig. 6).

\section{DISCUSSION}

Arteaga et al. (2017) recently provided a molecular phylogeny of the genus Atractus (with emphasis on the Ecuadorian species) based on three mitochondrial genes and including approximately $20 \%$ of the generic diversity. That study (with unprecedented taxonomic sampling for the genus) improved much of our knowledge about some specific relationships and supported Atractus badius as unrelated to the remaining Guiana Shield species. We herein confirm A. badius as an independent lineage related to Guiana Shield taxa (Fig. 1), which is corroborated by its distinctive hemipenial morphology (Fig. 5). Savage (1960) reviewed the Ecuadorian species of Atractus and proposed three species groups to accommodate the diversity known at that 

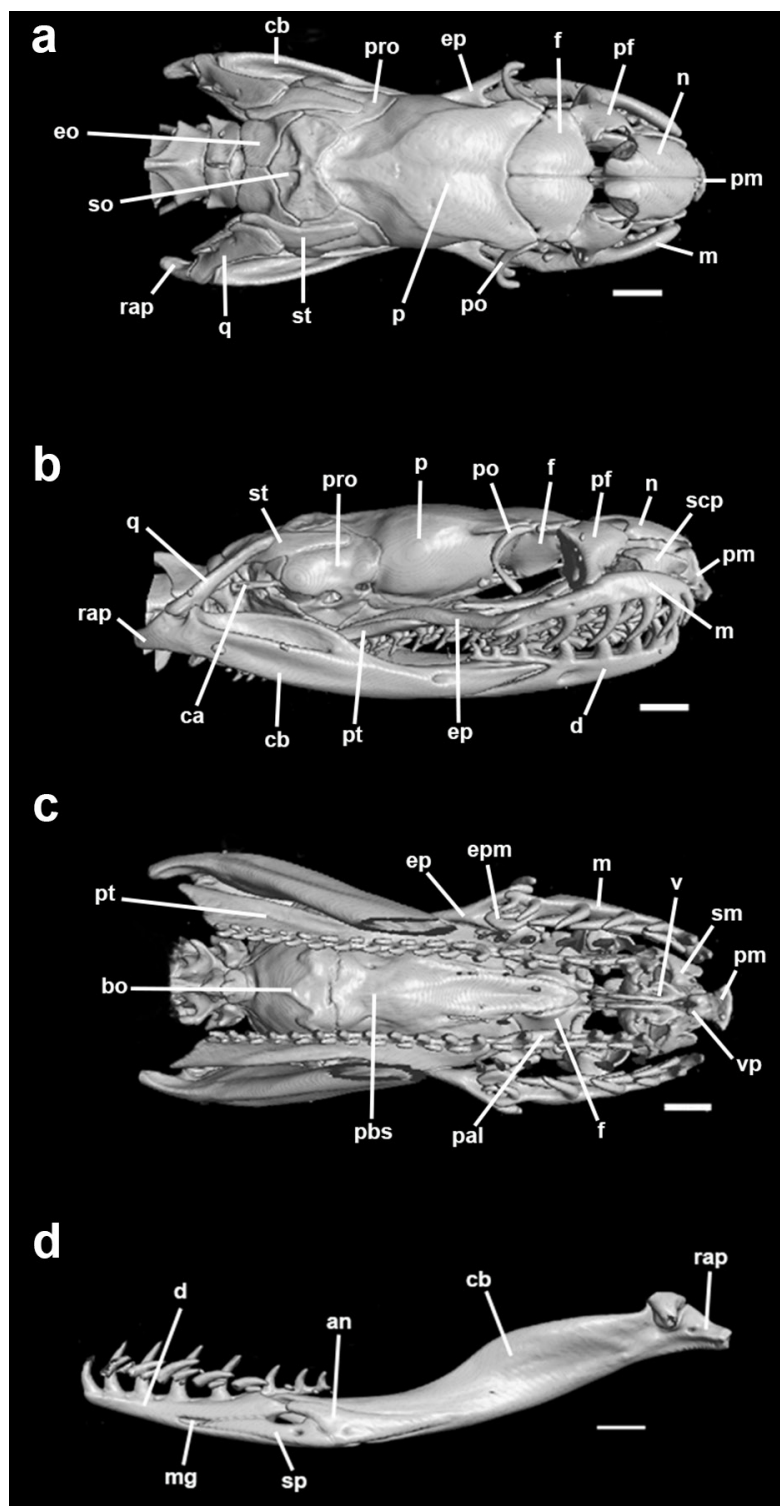

e

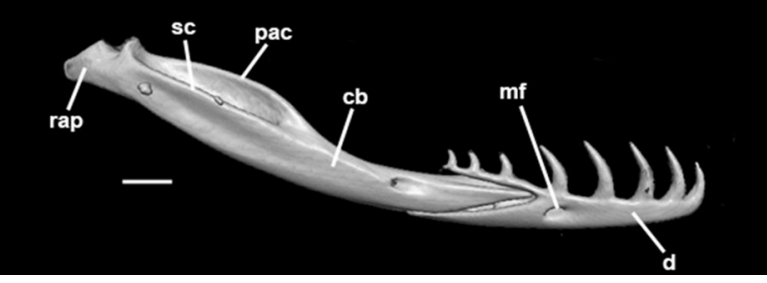

Figure 4. Dorsal (a), lateral (b), and ventral (c) views of the skull and lingual (d) and lateral (e) views of the mandible of Atractus badius based on $\mu$-CT of the specimen (MNRJ 26712) from Route du Galion, French Guiana. Scale bar $=2 \mathrm{~mm}$. The abbreviations are as follows: $\mathrm{pm}=$ premaxilla, $\mathrm{n}=$ nasal, $\mathrm{pf}=$ prefrontal, $\mathrm{scp}=$ conchal process of septomaxilla, $\mathrm{m}=$ maxilla, $f=$ frontal, $p=$ parietal, $p o=$ postocular, $c b=c o m p o u n d$ bone, pro=prootic, so=supraoccipital, eo=exoccipital, rap=retro-articular process, sm=septomaxilla, st=supratemporal, q=quadrate, ca=columela, pt=pterygoid, ep=ectopterygoid, $d=$ dentary, pal=palatine, $v=$ vomer, $v p=$ vomerian process, epm=ectopterygoid process, pbs=parabasiphenoid, bo=basioccipital, pac=prearticular crest, sc=surangular crest, an=angular, $\mathrm{mg}=$ Meckel's groove, $\mathrm{sp=splenial,}$ and $\mathrm{mf}=$ =mentonian foramen.

time. The Atractus badius group was defined by possession of the 'differentiate' condition (= capitulated organs) in the hemipenial morphology, but the nominal species of the group is not autochthonous to Ecuador (Savage 1960, Hoogmoed 1980). Hoogmoed (1980) provided a brief hemipenial description of $A$. badius based on its dissected and completely retracted organ, providing a limited number of characters for comparison with other congeners. We recovered $A$. badius in a highly supported clade with A. favae and A. trilineatus (Fig. 1). Unfortunately, we only had access to females of A. favae and its hemipenial morphology remains only known from its completely retracted condition (see Hoogmoed 1980). In addition, we obtained an unstable position of Atractus favae in both molecular analyses. Considering some hemipenial similarities (Fig. 5), A. badius shares a nearly bicapitate and bicalyculate organ with A. paisa (Passos et al. 2009a). However, other endemic species from the Cauca Valley in the Colombian Andes display a similar condition of the hemipenial ornamentation and general lobular structure (Passos 2008). We anticipate the possibility that some of them may be recovered in this clade once more species from the Andes of Colombia are incorporated in a 


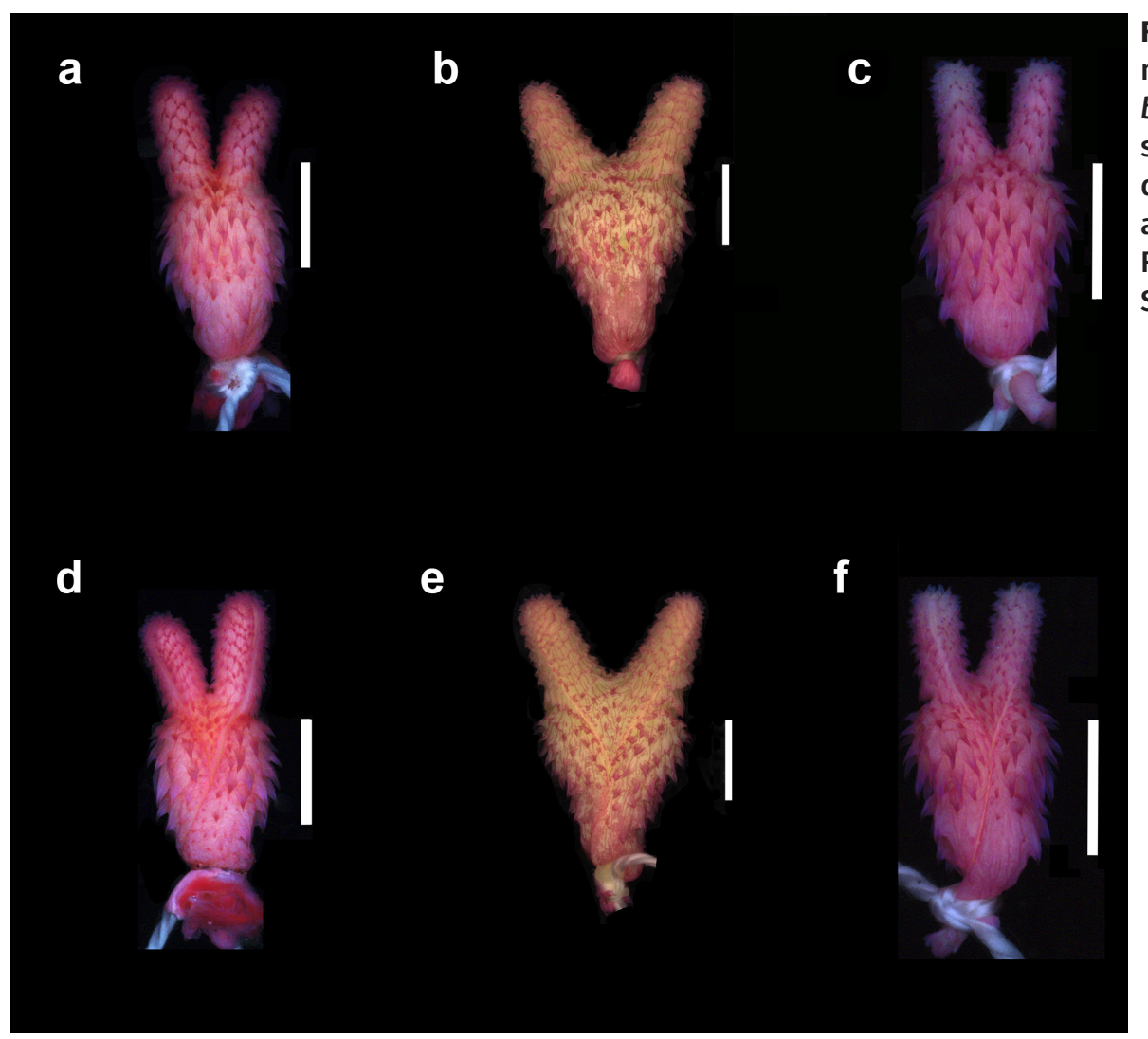

Figure 5. Hemipenial morphology of Atractus badius in asulcate (top) and sulcate (bottom) sides from a, d - AF1558, b, e - MNRJ 26711 and c, f - MNRJ 26714 from French Guiana (Appendix I). Scale bar $=5 \mathrm{~mm}$. broader phylogenetic study. Such hemipenial morphology does not occur in any other congener (Passos 2008). Consequently, we herein restrict the $A$. badius group to the nominal species waiting for new phenotypic or molecular evidences to render natural groups, even because two of the three Savage's species groups were recovered in the same clade (Fig. 1).

The diagnosis of Atractus pyroni was presented in its original description (Arteaga et al. 2017:102 p., Table 3). Arteaga and colleagues began by stating that the holotype of Atractus pyroni is an adult male (Arteaga et al. 2017:111 p.). However, in their figure 7 (Arteaga et al. 2017:112 p.) the caption presents the specimen as an adult female. The authors provided some additional morphological comparative data for the Atractus roulei species group (A. carrioni, 'A. lehmanni', A. pyroni and A. roulei). However, the meristic, pholidosis, and color pattern characters of $A$. pyroni completely overlap with those from A. roulei (Table III). Arteaga and colleagues distinguished $A$. pyroni from A. roulei by 'a distinct bicolored pattern'. Nonetheless, such supposedly different pattern of A. pyroni from the typical uniformly or reticulated colored A. roulei (see its color variation on the left margin of the Fig. 1) is because the specimen has been collected and preserved with partially retained ecdysis (Fig. 7 Arteaga et al. 2017:112 p., Fig. 7 from the present study). Consequently, the first author easily removed the outermost layer of some scales from the holotype of A. pyroni (= oberhäutchen, Fig. $7 d$ ), revealing uniform coloration typical from A. roulei. Furthermore, all meristic data from their specimen of 'A. lehmanni' also overlap with those from $A$. roulei. One of us (PP) also examined nearly all the specimens used by Arteaga et al. (2017), for this clade: a female holotype of Atractus pyroni 


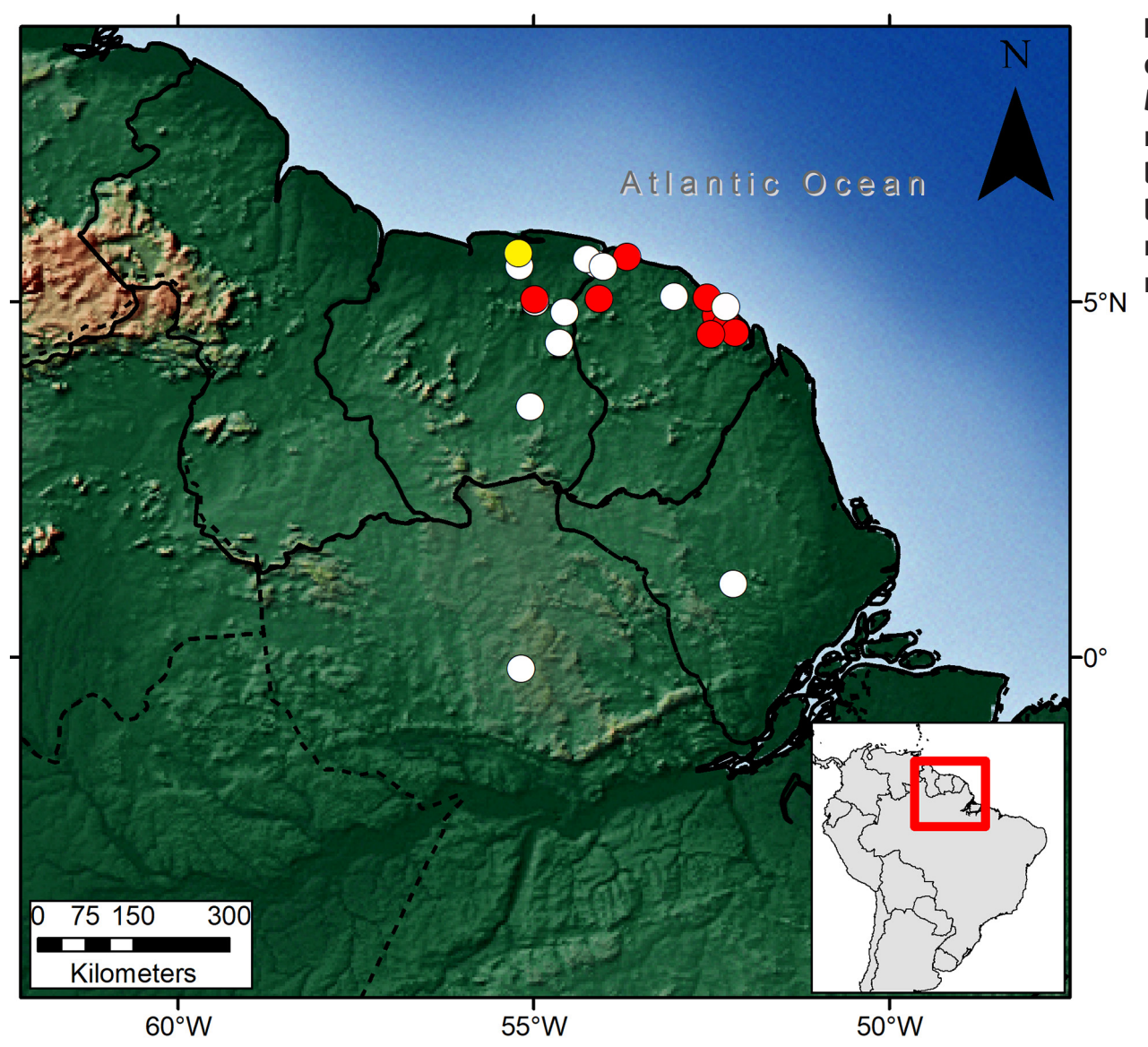

Figure 6. Geographical distribution of Atractus badius. Yellow circle represents the typelocality, white circles literature records and red circles the new records provided herein.

(MZUTI 5107), a male specimen of 'Atractus lehmanni' (DHMECN 7644) and a female specimen of Atractus roulei (DHMECN 7645). We found no phenotypic differences among them, since all specimens possess dorsal scale rows in $15 / 15 / 15$, supralabials six $\left(3^{\text {rd }}\right.$ and $4^{\text {th }}$ contacting the orbit), infralabials six (three or four contacting chinshields), postocular single, temporals $1+2$, maxillary teeth 10 (not eight as reported by Arteaga et al. 2017) or 11, preventrals 0-2, ventrals 142-145 in females, subcaudals 21 in female, and 28 in male, and similar dorsal and ventral coloration (Table III).

Boettger (1898), in the original description of Atractus lehmanni, diagnosed the species by having the following combination of characters: dorsal scales rows in 17/17/17; supralabials seven (four or five infralabials in contact with chinshields); postoculars two; incomplete reddish-white nuchal collar, dark-brown to black dorsum with reddish white tip of scales; venter black with reddish white square blotches; ventrals in females 148-153, 142-144 in males; subcaudals 20-21 in females, 25-27 in males. Later, Savage (1960) described the color pattern and the inverted condition for the hemipenis of A. lehmanni based on one male syntype (currently a paralectotype; see Mertens 1967). There is no reason to assume that specimens of A. lehmanni or A. roulei present such a disparate variation in many phenotypic traits. This fact could be checked through consultation of public repository as GBIF, in which photos of the lectotype of Atractus lehmanni are available or perhaps directly examining the available types. For that reason, the simplistic explanation based on available evidence suggests a misidentification of the Arteaga's 
Table III. Meristic and morphometric variation for the holotypes of Atractus pyroni and A. roulei, and the syntypes of $A$. lehmanni, as well as additional samples of $A$. roulei. The range of each continuous variable is from our own sample, except for A. lehmanni in which we are based on Boettger (1898) complemented with high-resolution photographs from the type-series. Abbreviations correspond to: SVL (snout-vent length), TL (tail length) and “-" (unknown data). The numbers in parentheses represent the total number of individuals available in collections for each sex. We placed together for both sexes the variables lacking secondary dimorphism. The holotypes of $A$. pyroni and $A$. roulei are marked in bold.

\begin{tabular}{|c|c|c|c|c|c|c|}
\hline Variable & $\begin{array}{c}\text { Atractus } \\
\text { pyroni }\end{array}$ & \multicolumn{2}{|c|}{ Atractus roulei } & $\begin{array}{l}\text { Atractus } \\
\text { roulei }\end{array}$ & \multirow{2}{*}{\multicolumn{2}{|c|}{$\begin{array}{c}\text { Atractus lehmanni } \\
\text { syntypes }\end{array}$}} \\
\hline \multirow[b]{2}{*}{ Sex } & \multirow{2}{*}{$\begin{array}{c}\text { holotype } \\
\text { female }\end{array}$} & \multirow[b]{2}{*}{ females (4) } & \multirow[b]{2}{*}{ males (4) } & \multirow{2}{*}{$\begin{array}{c}\text { holotype } \\
\text { female }\end{array}$} & & \\
\hline & & & & & females (3) & males (3) \\
\hline Ventrals & 145 & $142-150$ & $135-146$ & 154 & 148-153 & $142-144$ \\
\hline Subcaudals & 15 & $16-21$ & $23-28$ & 22 & $20-21$ & $25-27$ \\
\hline Maximum SVL & 437 & $395 \mathrm{~mm}$ & $340 \mathrm{~mm}$ & 409 & 296 & 262 \\
\hline TL/SVL ratio & $7.8 \%$ & $9.2-10.6 \%$ & $12.7-15.7 \%$ & $9.1 \%$ & $10.8 \%$ & $12.6 \%$ \\
\hline Dorsals & 15/15/15 & \multicolumn{2}{|c|}{ 15/15/15 (8) } & 15/15/15 & \multicolumn{2}{|c|}{$17 / 17 / 17$} \\
\hline Postoculars & $1 / 1$ & \multicolumn{2}{|c|}{$1 / 1(7)$ or $2 / 2(1)$} & $1 / 1$ & \multicolumn{2}{|c|}{$2 / 2$} \\
\hline Supralabials & $6 / 6$ & \multicolumn{2}{|c|}{$6 / 6(8)$} & $6 / 6$ & \multicolumn{2}{|c|}{$7 / 7$} \\
\hline Infralabials & $6 / 6$ & \multicolumn{2}{|c|}{$6 / 6(7)$ or $7 / 7(1)$} & $6 / 6$ & \multicolumn{2}{|c|}{$7 / 7$} \\
\hline Infralabials contacting chinshields & 4 & \multicolumn{2}{|c|}{$3(6)$ or $4(2)$} & 3 & \multicolumn{2}{|c|}{4 or 5} \\
\hline Gular scale rows & 2 & \multicolumn{2}{|c|}{$2(2)$ or $3(6)$} & 3 & \multicolumn{2}{|c|}{4} \\
\hline Preventrals & 0 & \multicolumn{2}{|c|}{$0(1), 1(1), 2(3), 3(2)$ or $4(1)$} & 0 & \multicolumn{2}{|c|}{$3(1), 4(2), 5(2)$ or $6(1)$} \\
\hline Maxillary teeth & 10 & \multicolumn{2}{|c|}{$9(1), 10(2)$ or $11(5)$} & - & \multicolumn{2}{|c|}{-} \\
\hline
\end{tabular}

terminal to 'Atractus lehmanni'. Therefore, Atractus lehmanni should be placed out from the $A$. roulei species group as early conceived by Passos et al. (2013b). Additionally, Arteaga et al. (2017) tentatively differentiated A. pyroni from A. roulei by the larger size SVL $437 \mathrm{~mm}(443 \mathrm{~mm}$ in Arteaga et al. 2017) of A. pyroni vs. maximum $396 \mathrm{~mm}$ in A. roulei. However, the description of $A$. roulei, where is stated the total length of $450 \mathrm{~mm}$ in the holotype (Despax 1910:370 p.) is just slightly lower than $471 \mathrm{~mm}$ of total length of A. pyroni. These differences are unsatisfying to recognize both as distinct species, since snakes present continuous growth and older specimens tend to be larger (see Greene 1997). Atractus pyroni represents maximum size for northern samples of $A$. roulei. Such allometric features are very common among Pacific populations of Atractus (see Passos et al. 2009b), and may be related with altitudinal gradient. Finally, and also more importantly, by recognizing $A$. pyroni as a valid species we have made $A$. roulei paraphyletic (Fig. 1). The alternative taxonomic posture implies recognizing three or four species 

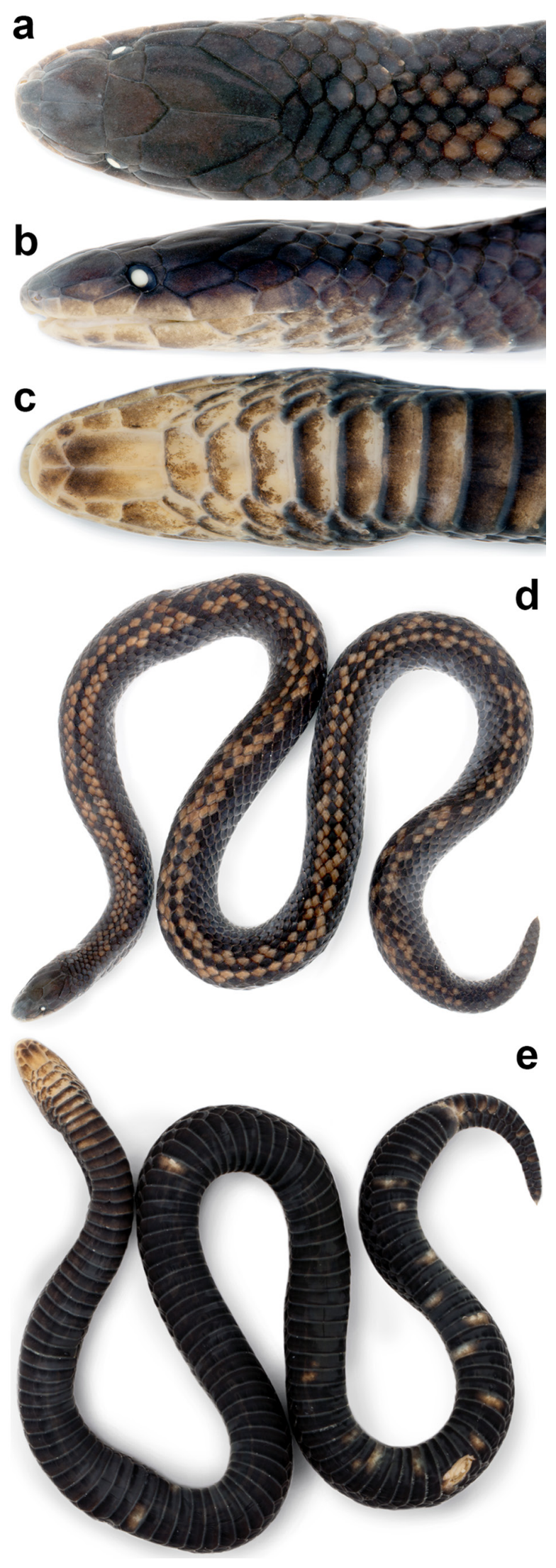

Figure 7. Dorsal (a), lateral (b) and ventral (c) views of head, and dorsal (d) and ventral (e) views of body of the holotype of Atractus pyroni (MZUTI 5107; SVL 437 $\mathrm{mm}, \mathrm{TL} 34 \mathrm{~mm}$ ) from locality between Balzapamba and Bilován (1.83601S, 79.13322W; $2026 \mathrm{~m}$ above sea level), province of Bolivar, Ecuador.

in order to restore the reciprocal monophyly of A. pyroni and A. roulei. However, as highlighted above both are not diagnosable on the basis of available morphological evidence. Therefore, given the data gathered in the course of study, we propose herein the formal synonymy of $A$. pyroni with A. roulei.

The inaccurate identifications of Atractus species in molecular phylogenies are more common than previously thought (above 30\% of sequences or specimens available in GenBank are misidentified or doubtfully identified with respect to the study that produced such sequences; Table I). As pointed out by Tautz et al. (2003), DNA-based systematics must be firmly anchored within the knowledge, concepts, techniques and infrastructure of traditional taxonomy. More importantly, 'DNA-taxonomy' will have to be based mainly on sequences from newly collected individuals identified by experienced taxonomists (Tautz et al. 2003:71 p.). We argue that such caveats are less harmful for the macro-evolutionary or macro-ecological studies in which the focus is not direct towards promoting taxonomic changes or nomenclatural acts. Still, there have been systematic-based studies in which authors abstained to make shifts for taxa or clades with complex and/or unresolved taxonomy (see Pinna et al. 2018) and, sometimes, less representativeness of species as terminals (Grazziotin et al. 2012, Zaher et al. 2014). By contrast, we believe that there are three main hierarchical levels of implications to this question: (i) as DNA databases grow exponentially (e.g., GenBank, BOLD), the use of misidentified sequences and even chimeras, strictly with species-level taxonomic proposal represents a real peril; (ii) phylogenies built 
upon sequences without associated vouchers prevents from the possibility of falsifying first identification hypotheses for the new sequences added to a public repository; (iii) deliberate non-availability of data associated with uploaded sequences at GenBank, such as detailed location of the voucher collection have been omitted (e.g., Hamdan et al. 2017). Although the issues highlighted above are increasing fast with the reduction of the cost and new sequencing techniques, they affect the taxonomy of some groups disproportionately, notably for some snakes. As a rule, historically the snakes' sampling efforts, and availability of geographically balanced samples of taxa with secretive lifestyle both are elusive. Besides, some cryptozoic snakes, as Atractus, differ from other vertebrate groups in presenting a few locally exhaustively sampled regions, but with many subsampled portions along species distribution range. To complicate this matter, many Atractus species are apparently rare with supposedly restricted endemism, only because of the lack of knowledge (de Fraga et al. 2017), making the geographic range of variation of local samples sometimes unpredictable. Therefore, we claim to authors improving the accuracy on species identifications, integrating the data with exhaustive comparisons, prior to split new names and traditional taxa concepts, considering the long-standing (and functional) taxonomic system (Pinna et al. 2018).

\section{Acknowledgments}

First author thanks J. Valencia, D. Salazar-Valenzuela, M. Yanez-Muñoz, K. de Queiroz, R. Wilson and H. Zaher for allowing the examination of the specimens under their care. We thank D. Kizirian, L. Vonnahme, A. Kupfer, S. Schweiger, G. Gassner, A. Schumacher, F. Starace, B. Dupont, S. Sant and F. Deschandol for providing data or images of Atractus badius, and BioWeb Ecuador for the photos of A. roulei. PP and LOR are deeply indebted to R. Lopez for the high resolution $\mu \mathrm{CT}$ images generated in the Nuclear Instrumentation Laboratory of the Universidade Federal do Rio de Janeiro (UFRJ). PP was supported by Conselho Nacional de Desenvolvimento
Científico e Tecnológico (CNPq) and Fundação Carlos Chagas Filho de Amparo à Pesquisa do Estado do Rio de Janeiro (FAPERJ). Molecular work and fieldwork by OTC were funded by Secretaría de Educación Superior, Ciencia, Tecnología y Innovación (SENESCYT), under the 'Arca de Noé' Initiative. AF benefited from "Investissement d'Avenir" grants managed by the Agence Nationale de la Recherche (CEBA; \#ANR-10-LABX-25-01, TULIP \#ANR-10LABX-41, \#ANR-11-IDEX-0002-02). PRMS specially thanks M. T. Rodrigues and team by friendship and facilities in Universidade de São Paulo (USP) and granted tissues. PRMS was supported by Coordenação de Aperfeiçoamento de Pessoal de Nivel Superior (CAPES) fellow (88882.183267/2018-01) during this work.

\section{REFERENCES}

ABUYS A. 1983. The snakes of Surinam. Part VI: subfamily Xenodontinae (general data and genus Atractus). Litt Serp 3: 67-81.

ARTEAGA A, MEBERT K, VALENCIA JH, CISNEROS-HEREDIA DF, PEÑAFIEL N, REYES-PUIG C, VIEIRA-FERNANDES JL \& GUAYASAMIN JM. 2017. Molecular phylogeny of Atractus (Serpentes, Dipsadidae), with emphasis on Ecuadorian species and the description of three new taxa. Zookeys 661: 91-123.

ÁVILA-PIRES TCS, HOOGMOED MS \& ROCHA WA. 2010. Notes on the vertebrates of northern Pará, Brazil: a forgotten part of the Guianan Region, I. Herpetofauna. Bol Mus Para Emílio Goeldi Ser Cienc Nat 5(1): 13-112.

BLAIR C, MENDEZ DE LA CRUZ FR, NGO A, LINDELL J, LATHROP A \& MURPHY RW. 2009. Molecular phylogenetics and taxonomy of leaf-toed geckos (Phyllodactylidae: Phyllodactylus) inhabiting the peninsula of Baja California. Zootaxa 2027: 28-42.

BOETTGER O. 1898. Katalog der Reptilien-Sammlung im Museum der Senckenbergischen Naturforschenden Gesellschaft in Frankfurt/M. 2.Teil (Schlangen). Frankfurt, $160 \mathrm{p}$

BOIE H. 1827. Bemerkungen Über Merrem's Verfuch eines Systema der Amphibien. Isis von Oken 20: 508-565.

BOULENGER GA. 1894. Catalogue of the snakes in the British Museum (Natural History), vol. 2. London, Trustees of the British Museum, $382 \mathrm{p}$.

CARRILLO N \& ICOCHEA J. 1995. Lista taxonómica preliminar de los reptiles vivientes del Perú. Publ Mus Hist Nat, Univers Nac San Marcos 47: 1-27.

CHIPPAUX JP. 1986. Les Serpents de la Guyane Française. Paris, Ostrom, $165 \mathrm{p}$.

CUNDALL D \& IRISH F. 2008. The snake skull. In: Gans C, Gaunt AS \& Adler K (Eds), Biology of Reptilia Vol. 20, The 
skull of Lepidosauria. New York, Society for the Study of Amphibians and Reptiles Press, 349-692 p.

DE FRAGA R, ALMEIDA AP, MORAES LCJ, GORDO M, PIRANI R, ZAMORA RR, CARVALHO VT, PASSOS P \& WERNECK FP. 2017. Narrow endemism or insufficient sampling? Geographic range extension and morphological variation of the poorly known Atractus riveroi Roze, 1961 (Serpentes: Dipsadidae). Herp Rev 48(2): 281-284.

DESPAX R. 1910. Mission géodésique de l'Équateur. Collections recueillies par $M$. le Dr Rivet. Liste des ophidiens et descriptions des espèces nouvelles. (Note préliminaire.). Bull Mus Natl Hist Natur Paris 16: 368-376.

DOWLING HG. 1951. A proposed standard system of counting ventrals in snakes. Brit J Herp 1: 97-99.

DRUMMOND AJ, SUCHARD MA, XIE D \& RAMBAUT A. 2012. Bayesian phylogenetics with BEAUti and the BEAST 1.7. Mol Biol Evol 29: 1969-1973.

DUMÉRIL AMC, BIBRON G \& DUMÉRIL AHA. 1854. Erpétologie Générale ou Histoire naturelle Complète des Reptiles, vol. 7. Paris: Librairie Encyclopédique de Roret, 1536 p.

FIGUEROA A, MCKELVY AD, GRISMER LL, BELL CD \& LAILYAUX SP. 2016. A species-level phylogeny of extant snakes with description of a new colubrid subfamily and genus. PLoS ONE 11: 1-31.

GIRAUDO AR \& SCROCCHI G. 2000. The genus Atractus (Serpentes: Colubridae) in north-eastern Argentina. Herp J 10: 81-90.

GRAZZIOTIN FG, ZAHER H, MURPHY RW, SCROCCHI G, BENAVIDES MA, ZHANG Y \& BONATTO SL. 2012. Molecular phylogeny of the New World Dipsadidae (Serpentes: Colubroidea): a reappraisal. Cladistics 2012: 1-23.

GREENE HW. 1997. Snakes: the evolution of mystery in nature. Berkeley, University of California Press, 366 p.

GÜNTHER A. 1858. Catalogue of Colubrine snakes of the British Museum. London, Trustees of the British Museum, $281 \mathrm{p}$.

HAMDAN B, PEREIRA AG, LOSS-OLIVEIRA L, RÖDDER D \& SCHRAGO CG. 2017. Evolutionary analysis of Chironius snakes unveils cryptic diversity and provides clues to diversification in the Neotropics. Mol Phyl Evol 116: 108-119.

HOEGG S, VENCES M, BRINKMANN H \& MEYER A. 2004. Phylogeny and comparative substitution rates of frogs inferred from sequences of three nuclear genes. Mol Biol Evol 21: 1188-1200.

HOOGMOED MS. 1980. Revision of the genus Atractus in Surinam, with the ressurection of two species (Colubridae, Reptilia). Notes on the Herpetofauna of Surinam VII. Zool Verh 175: 1-47.

HOOGMOED MS \& ÁVILA-PIRES TCS. 1991. Annotated checklist of the herpetofauna of Petit Saut, Sinnamary River, French Guiana. Zool Meded 65(5): 53-88.
JAN G. 1862. Enumerazione sistematico delle specie d'ofidi del gruppo Calamaridae. Arc Zool Anat Fisiol 2: $1-76$.

KENDALL S, YEO M, HENTTU P \& TOMLINSON DR. 2000. Alternative splicing of the Neurotrophin-3 gene gives rise to different transcripts in a number of human and rat tissues. Jour Neur 75: 41-47.

KÖHLER G \& KIECKBUSCH M. 2014. Two new species of Atractus from Colombia (Reptilia, Squamata, Dipsadidae). Zootaxa 3872(3): 291-300.

KUMAR S, STECHER G \& TAMURA K. 2016. MEGA7: molecular evolutionary genetics analysis version 7.0 for bigger datasets. Mol Biol Evol 33: 1870-1874.

LANFEAR R, FRANDSEN PB, WRIGHT AM, SENFELD T \& CALCOTT B. 2016. Partitionfinder 2: new methods for selecting partitioned models of evolution for molecular and morphological phylogenetic analyses. Mol Biol Evol 34: 772-773.

MELO-SAMPAIO PR, PASSOS P, FOUQUET A, PRUDENTE ALC \& TORRES-CARVAJAL O. 2019. Systematic review of Atractus schach (Serpentes: Dipsadidae) species complex from the Guiana Shield with description of three new species. Syst Biodivers 17(3): 207-229.

MELO-SAMPAIO PR, PASSOS P, PRUDENTE ALC, VENEGAS PJ \& TORRES-CARVAJAL O. 2021. Systematic review of the polychromatic ground snakes of the Atractus snethlageae complex reveals four new species from threatened environments. J Zool Syst Evol Res 59(3): 718-747.

MERTENS R. 1967. Die herpetologische sektion des NaturMuseums und forschungs-Institutes Senckenberg in Frankfurt a. M. nebst einem Verzeichnis ihrer Typen. Senckenb Biol (1): 1-106.

MYERS CW. 2003. Rare snakes-Five new species from eastern Panama: reviews of northern Atractus and southern Geophis (Colubridae: Dipsadinae). Am Mus Nov 3391: 1-47.

PASSOS P. 2008. Revisão taxonômica do gênero Atractus Wagler, 1828 (Serpentes: Colubridae: Dipsadinae). PhD Thesis, Rio de Janeiro, Universidade Federal do Rio de Janeiro, Museu Nacional, Brazil, 671 p.

PASSOS P, ARREDONDO JC, FERNANDES R \& LYNCH JD. 2009a. Three new Atractus (Serpentes: Dipsadidae) from the Andes of Colombia. Copeia 2009: 425-436.

PASSOS P, AZEVEDO JAR, NOGUEIRA CC, FERNANDES R \& SAWAYA RJ. 2019a. An integrated approach to delimit species in the puzzling Atractus emmeli complex (Serpentes: Dipsadidae). Herp Monogr 33: 1-25.

PASSOS P, CHIESSE A, TORRES-CARVAJAL O \& SAVAGE JM. 2010. Testing species boundaries within the Atractus occipitoalbus complex (Serpentes: Dipsadidae). Herpetologica 65(4): 384-403. 
PASSOS P, ECHEVARRÍA L \& VENEGAS PJ. 2013b. Morphological variation of Atractus carrioni. S Amer Jour Herp 8: 109-120.

PASSOS P, KOK PJR, ALBUQUERQUE NR \& RIVAS G. $2013 \mathrm{a}$. Groundsnakes of the Lost World: a review of Atractus (Serpentes: Dipsadidae) from the Pantepui region, northern South America. Herpetol Monogr 27: 52-86.

PASSOS P, MARTINS A \& PINTO-COELHO D. 2016. Population morphological variation and natural history of Atractus potschi (Serpentes: Dipsadidae) in Northeastern Brazil. S Am Jour Herp 11: 188-211.

PASSOS P, MUESES-CISNEROS JJ, LYNCH JD \& FERNANDES R. 2009b. Pacific lowland snakes of the genus Atractus (Serpentes: Dipsadidae), with description of three new species. Zootaxa 2293: 1-34.

PASSOS P \& PRUDENTE ALC. 2012. Morphological variation, polymorphism, and taxonomy of the Atractus torquatus complex (Serpentes: Dipsadidae). Zootaxa 3407: 1-21.

PASSOS P, PRUDENTE ALC, RAMOS LO, CAICEDO-PORTILLA JR \& LYNCH JD. 2018b. Species delimitations in the Atractus collaris complex (Serpentes: Dipsadidae). Zootaxa 4392(3): 491-520.

PASSOS P, RAMOS LO, FOUQUET A \& PRUDENTE ALC. 2017. Taxonomy, morphology, and distribution of Atractus flammigerus Boie 1827 (Serpentes: Dipsadidae). Herpetologica 73: 349-363.

PASSOS P, SCANFERLA A, MELO-SAMPAIO PR, BRITO J \& ALMENDÁRIZ A. 2019b. A giant on the ground: another large-bodied Atractus (Serpentes: Dipsadinae) from Ecuadorian Andes, with comments on the dietary specializations of the goo-eaters snakes. An Acad Bras Cienc 91: 1-14.

PASSOS P, SUDRÉ V, DORIA G \& CAMPBELL P. 2018a. The taxonomic status of the "forgotten" Bolivian snakes, Atractus balzani Boulenger 1898 and Atractus maculatus (sensu Boulenger 1896) (Serpentes: Dipsadidae). Zootaxa 4438: 176-182.

PÉREZ-SANTOS C \& MORENO AG. 1988. Ofidios de Colombia. Museo Regionale di Scienze Naturali Torino Monographie VI, p. 1-512.

PESANTES O. 1994. A method for preparing hemipenis of preserved snakes. J Herp 28: 93-95.

PETERS JA \& OREJAS-MIRANDA B. 1986. Catalogue of the Neotropical Squamata: Part I: Snakes. Revisited edition (originally published in 1970), Addenda and corrigenda by Vanzolini, P.E. Washington DC, Smithsonian Institution, 293 p.

PINNA PH, FERNANDES DS \& PASSOS P. 2018. "If you choose not to decide you still have made a choice". Bionomina 13: 65-68.

PRICE RM. 1982. Dorsal snake scale microdermatoglyphics: ecological indicator or taxonomic tool? J Herp 16: 294-306.
PRICE RM \& KELLY P. 1989. Microdermatoglyphics: basal patterns and transition zones. J Herp 23: 244-261.

PYRON RA, ARTEAGA A, ECHEVARRÍA LY \& TORRES-CARVAJAL O. 2016. A revision and key for the tribe Diaphorolepidini (Serpentes: Dipsadidae) and checklist for the genus Synophis. Zootaxa 4171: 293-320.

PYRON RA, BURBRINK FT \& WIENS JJ. 2013. A phylogeny and revised classification of Squamata, including 4161 species of lizards and snakes. BMC Evol Biol 13: 153.

PYRON RA, GUAYASAMIN JM, PEÑAFIEL N, BUSTAMANTE L \& ARTEAGA A. 2015. Systematics of Nothopsini (Serpentes, Dipsadidae), with a new species of Synophis from the Pacific Andean slopes of southwestern Ecuador. ZooKeys 541: 109-147.

RONQUIST F, TESLENKO M, VAN DER MARK P, AYRES DL, DARLING A, HÖHNA S, LARGET B, LIU L, SUCHARD MA \& HUELSENBECK JP. 2012. MRBAYES 3.2: Efficient Bayesian phylogenetic inference and model selection across a large model space. Syst Biol 61: 539-542.

SABAJ MH. 2020. Codes for Natural History collections in ichthyology and herpetology. Copeia 108(3): 593-669.

SAVAGE JM. 1960. A revision of the Ecuadorian snakes of the colubrid genus Atractus. Misc Publ Mus Zool Univ Mich 112: 1-86.

STAMATAKIS A. 2014. RAXML version 8: a tool for phylogenetic analysis and post-analysis of large phylogenies. Bioinformatics 30(9): 1312-1313.

STARACE F. 1998. Guide de Serpents et Amphisbénes de Guyane. Paris, Gadeloupe, Ibis Rouge, 448 p.

SULLIVAN J \& JOYCE P. 2005. Model selection in phylogenetics. Ann Rev Ecol Evol Syst 36: 445-466.

TAUTZ D, ARCTANDER P, MINELLI A, THOMAS RH \& VOGLER AP. 2003. A plea for DNA taxonomy. T Ecol Evol 18: 70-74.

THOMPSON JD, HIGGINS DG \& GIBSON TJ. 1994. CLUSTAL W: improving the sensitivity of progressive multiple sequence alignment through sequence weighting, position-specific gap penalties and weight matrix choice. Nuc Ac Res 22: 4673-4680.

UETZ P, FREED P \& HOSEK J (Eds). 2021. The Reptile Database. Electronically accessible at http:// reptile-database.org.

UZZELL T. 1973. A revision of the genus Prionodactylus with a new genus for $P$. leucostictus and notes on the genus Euspondylus (Sauria, Teiidae). Postilla 159: 1-67.

VAIDYA G, LOHMAN DJ \& MEIER R. 2011. SequenceMatrix: concatenation software for the fast assembly of multigene datasets with character set and codon information. Cladistics 27: 171-180.

WAGLER JG. 1828. Auszüge aus seinem Systema Amphibiorum. Isis von Oken 21: 740-744. 
WAGLER JG. 1830. Natürliches System der Amphibien mit vorangehender Classification der Säugethiere und Vögel. Munich, J.G. Cotta, 354 p.

ZAHER H. 1999. Hemipenial morphology of the South American xenodontine snakes, with a proposal for a monophyletic Xenodontinae and a reappraisal of colubroid hemipenes. Bull Am Mus Nat Hist 240: 1-168.

ZAHER H, GRAZZIOTIN FG, CADLE JE, MURPHY RW, MOURA-LEITE JC \& BONATTO SL. 2009. Molecular phylogeny of the advanced snakes (Serpentes, Caenophidia), with an emphasis on South American xenodontines: a revised classification and descriptions of new taxa. Pap Avul Zool 49: 115-153.

ZAHER H, DE OLIVEIRA L, GRAZZIOTIN FG, CAMPAGNER M, JARED C, ANTONIAZZI MM \& PRUDENTE ALC. 2014. Consuming viscous prey: a novel protein-secreting delivery system in neotropical snail-eating snakes. BMC Evol Biol 14: 58.

\section{APPENDIX I}

Specimens examined of the Atractus badius (n=13). BRAZIL: Amapá: Oiapoque: (IBSP 24867). FRENCH GUIANA: unknown locality: (MZUSP four uncatalogued specimens), Roura: Kaw: (MNRJ 26710-11, 26714-15), Route du Galion: (MNRJ 26712), Chutes Voltaire: (MNRJ 26713), Maititi: Bagnes des Annamites: (MNRJ 26716), Cayenne: (USNM 438).

\section{How to cite}

PASSOS P, MELO-SAMPAIO PR, RAMOS LO, GRAZZIOTIN FG, FOUQUET A \& TORRES-CARVAJAL 0. 2022. When the tail shakes the snake: phylogenetic affinities and morphology of Atractus badius (Serpentes: Dipsadidae), reveals some current pitfalls on the snake's genomic age. An Acad Bras Cienc 94: e20191254. DOI 10.1590/0001-3765202220191254.

\section{ANTOINE FOUQUET ${ }^{3,4}$}

https://orcid.org/0000-0003-4060-0281

\section{OMAR TORRES-CARVAJAL ${ }^{5}$}

https://orcid.org/0000-0003-0041-9250

'Universidade Federal do Rio de Janeiro, Museu Nacional, Departamento de Vertebrados, Quinta da Boa Vista, s/n, 20940-040 Rio de Janeiro, RJ, Brazil

${ }^{2}$ Instituto Butantan, Laboratório Especial de Coleções Zoológicas, Avenida Vital Brazil, 1500, 05508-040 São Paulo, SP, Brazil

${ }^{3}$ Laboratoire Evolution \& Diversité Biologique, Université Toulouse III Paul Sabatier, Bâtiment 4R1 31062 cedex 9, 118 Route de Narbonne, 31077 Toulouse, France ${ }^{4}$ Laboratoire Écologie, Évolution, Interactions des Systèmes Amazoniens (LEEISA), USR 3456 (CNRS, IFREMER, Université de Guyane), Centre de Recherche de Montabo, Cayenne, French Guiana

${ }^{5}$ Museo de Zoología, Escuela de Biología, Pontificia Universidad Católica del Ecuador, Avenida 12 de Octubre y Roca, 1076, Apartado 17-01-2184, Quito, Ecuador

Correspondence to: Paulo Passos

E-mail:ppassos@mn.ufrj.br, atractus@gmail.com

\section{Author contributions}

PP: conceptualization, investigation, methods, formal analyses, funding, writing-review \& editing. PRMS: investigation, methods, formal analyses, writing-review \& editing. LOR: methods, formal analyses, writing-review \& editing. FGG, AF, OTC: methods, laboratory work, funding, writing-review \& editing.

\section{(cc) $B Y$}

Manuscript received on October 10, 2019;

accepted for publication on June 21, 2020

\section{PAULO PASSOS}

https://orcid.org/0000-0002-1775-0970

\section{PAULO R. MELO-SAMPAIO ${ }^{1}$}

https://orcid.org/0000-0003-1858-1643

\section{LUCIANA O. RAMOS ${ }^{1}$}

https://orcid.org/0000-0002-5190-5163

FELIPE G. GRAZZIOTIN ${ }^{2}$

https://orcid.org/0000-0001-9896-9722 